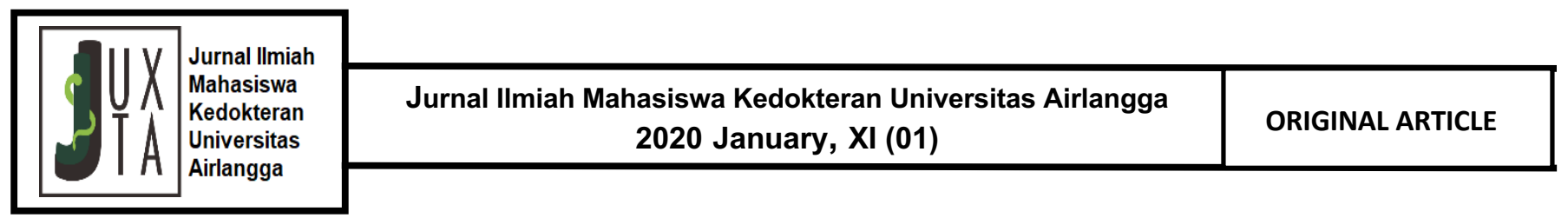

\title{
The Effect of Cigarette Smoke Exposure in the Fetal Growth and Fetal Development of Mice (Mus musculus)
}

\author{
Endy Novryan Ridwan ${ }^{1}$, Martono Tri Utomo ${ }^{2}$, Harianto Notopuro ${ }^{3}$ \\ ${ }^{1}$ Faculty of Medicine, Universitas Airlangga, Surabaya, Indonesia. \\ ${ }^{2}$ Department of Paediatrics, Faculty of Medicine, Universitas Airlangga - Dr. Soetomo General Hospital, Surabaya, Indonesia. \\ ${ }^{3}$ Department of Biochemistry, Faculty of Medicine, Universitas Airlangga, Surabaya, Indonesia.
}

\section{A B S T R A C T}

Introduction: This research aims to investigate and observe the effect of cigarette smoke exposure in the fetal growth and fetal development of mice (Mus musculus).

Methods: This was an experiment with post-test only control group design. The sample of the research was 36 pregnant mice which were randomly divided into 2 groups: control group $(\mathrm{K})$ pregnant mice which inhaled ambient air without cigarette smoke exposure, and treatment group $(P)$ pregnant mice which were given cigarette smoke exposure for 14 days with 2 bars of cigarette each day.

Results: The results showed a significant difference in the fetal birth weight between the group exposed to cigarette smoke $(p<0.05)$ compared with the control group. Fetal defect and stillbirth were not found in this research.

Conclusion: The exposure of cigarette smoke gave negative effects of fetal growth and development because of the free radicals generated.

* Correspondence: martono-t-u@fk.unair.ac.id

JUXTA: Jurnal IImiah Mahasiswa Kedokteran Universitas Airlangga

p-ISSN: 1907-3623; e-ISSN: 2684-9453

DOI: $10.20473 / j u x t a . V 11 / 12020.13-17$

Open access under Creative Commons Attribution-ShareAlike 4.0 International License (CC-BY-SA)

\section{ARTICLE INFO}

\section{Article history:}

Received 13 August 2019

Received in revised form 21

August 2019

Accepted 22 January 2020

\section{Keywords:}

Cigarette smoke,

Mice,

Fetal defect,

Stillbirth,

Fetal birth weight. 


\section{Introduction}

The use of tobacco as cigarettes is a major health problem in the world, especially in the middle-income and developing countries. Based on the data, tobacco killed 7 million people each year, 6 million people were killed as active smokers and 890.000 people were killed as passive smokers. ${ }^{1} 36.3 \%$ smokers were over the age of 15 . Most of them were male smokers with a prevalence of $64.9 \%$. Meanwhile, the prevalence in women increased from $5.2 \%$ in 2007 to $6.9 \%$ in 2013 . $^{2}$

Currently, there are 61.4 million smokers in Indonesia which makes it the third most active smokers in the world after China and India. ${ }^{3}$ Approximately $67 \%$ of men and $2.7 \%$ of women in Indonesia are smokers. The rate of exposure to cigarette smoke most often occurs in public places with a prevalence of around $85.4 \%$, followed by a home environment of $78.4 \%$, and in the workplace at $51.3 \%{ }^{4}$ Results of survey reveal that the number of female passive smokers in Indonesia is 62 million people and 30 million people are male. These passive smokers have a risk of developing cancer $30 \%$ greater than those who are not exposed to cigarette smoke. Passive smoker is also at risk for ischemic heart disease. Various efforts have been made to promote awareness and willingness of people not to smoke in public places, especially around pregnant women who are in immunodeficiency state and are very susceptible to diseases. ${ }^{5}$

Based on health and well-being paradigm by $\mathrm{H}$. L. Blum, there are four indirect determinant factors which are related to cause fetal death. The four factors are health services, health behaviour, environment, and genetic. In Indonesia, environmental factors are the biggest and the most difficult determinant factors to overcome. ${ }^{6}$

More than 3800 chemical compounds are found in cigarettes. The main components contained in one cigarette are nicotine $2.2-2.3 \mathrm{mg}$, tar 31 - $33 \mathrm{mg}$, carbon monoxide (CO) $5-23 \mathrm{mg}$, nitric acid $0.1-1.6 \mathrm{mg}$, acetaldehyde $0.2-1.3 \mathrm{mg}$, formic acid $0.1-1.1 \mathrm{mg}$, methyl chloride $0.1-0.8 \mathrm{mg}$, cyanide acid $0.03-0.7 \mathrm{mg}$, and 50 other types of carcinogens. The chemicals contained in cigarettes can cause imperfect sperm formation. The content of cigarette smoke can also cause the unsmooth flow of blood to the uterus. Thus smoking actively and passively can have an effect on fetal growth and development. $^{7}$

This research aims to determine the effect of passive exposure to cigarette smoke on the growth and development of the foetus, especially in experimental animal mice (Mus musculus).

\section{Methods}

This research was an experiment with post-test only control group design. This research was conducted at the Laboratory of Experimental Animal, Department of Biochemistry, Faculty of Medicine, Universitas Airlangga, Surabaya, from April to September, 2018.

The population in this research was female mice (Mus musculus) from the Laboratory of Experimental Animals, Department of Biochemistry, Faculty of Medicine, Universitas Airlangga. The sample was female mice (Mus musculus) obtained from the population. The sample was randomly divided into 2 groups. The sample size of each group was 16 . To anticipate subject loss, data loss, and damaged sample, the researched subjects were added as many as $10 \%$, so that the number of subjects became 18 , bringing the total sample to 36 samples. Sampling technique used was random sampling.

The inclusion criteria in this research was mice (Mus musculus) aged 7 to 8 weeks, weighing 18-35 grams, in a pregnant state and healthy physical condition. The exclusion criteria in this research was deformed mice (Mus musculus), sick (inactive movements), and died during the treatment or before the treatment.

Female mice (Mus musculus) were mated with male mice during the sexual cycle (estrus) of mice. The mating system used was a polygamy system (five females with one male). After doing the mating, a vaginal plug will be examined. Vaginal plugs are yellowish sperm originating from male mice gland secretions, it is used as a sign of establishing a 0 day pregnancy. Exposure to cigarette smoke was given starting on the $6^{\text {th }}$ day of pregnancy (organogenesis period). Exposure continued until the $19^{\text {th }}$ day (birth). The mice were exposed to 2 bars of cigarette each day which was divided into 2 times, carried out in the morning at $09.00 \mathrm{WIB}$ and in the afternoon at $15.00 \mathrm{WIB}^{8}$ The mice got 2 bars of cigarette exposure which are equivalent to 34 bars for humans (its is included in the classification of heavy smokers). After the foetus was born, observations were made on fetal birth defects, stillbirth, and fetal birth weight, then the results of the treatment group were compared with the results of the control group.

Data obtained from the subsequent tests were processed using the SPSS 24 computer program. In the data of birth defects and stillbirth mice, descriptive data analysis was conducted. Data on fetal birth weight were carried out by data distribution test and Homogeneity of Variance test, followed by Mann Whitney test. 


\section{Results}

The sample size in this research was 12 pregnant female mice, which fit the inclusion criteria, and were divided into a control group $(\mathrm{K})$ of female mice which were breathing in ambient air without exposure to cigarette smoke and the treatment group $(P)$ of female mice which were exposed to cigarette smoke. The number of fetal mice born from the control group was 70 and the treatment group was 66 .

Table 1. Distribution of Fetal Defect Data.

\begin{tabular}{cccc}
\hline Group & $\begin{array}{c}\text { Foetus } \\
\text { (es) }\end{array}$ & \multicolumn{2}{c}{ Foetus Born } \\
\cline { 3 - 4 } & & Normal & Defect \\
\hline Control (K) & 70 & $100 \%$ & 0 \\
$\begin{array}{c}\text { Treatment } \\
\text { (P) }\end{array}$ & 66 & $100 \%$ & 0 \\
& & & \\
& & & \\
& &
\end{tabular}

Source: research data, processed

${ }^{*}$ comparison between groups

Table 2. Distribution of Fetal Dead Data.

\begin{tabular}{cccc}
\hline Group & $\begin{array}{c}\text { Foetus } \\
\text { (es) }\end{array}$ & \multicolumn{2}{c}{ Foetus Born } \\
\cline { 3 - 4 } & & Normal & Dead \\
\hline Control (K) & 70 & $100 \%$ & 0 \\
Treatment & 66 & $100 \%$ & 0
\end{tabular}

(P)

Source: research data, processed

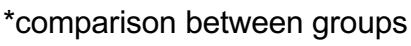

Based on the data in table 1 and table 2, no fetal defect and fetal dead was found in the control and treatment groups.

Table 3. Average Results and Deviation Standard of Fetal Birth Weight.

\begin{tabular}{cccc}
\hline Group & N & Mean & $\begin{array}{c}\text { Deviation } \\
\text { Standard }\end{array}$ \\
\hline Control (K) & 12 & 1.67 & 0.291 \\
Treatment (P) & 12 & 1.47 & 0.195 \\
\hline
\end{tabular}

Source: research data, processed

${ }^{*}$ comparison between groups

Based on the data in table 3, it showed that the highest average fetal birth weight was the control group (K), while the lowest fetal birth weight was the treatment group $(P)$.

Table 4. Results for Fetal Birth Weight Data of Normality Test.

\begin{tabular}{|c|c|c|c|}
\hline Group & $\mathbf{N}$ & Sig & Notes \\
\hline Control (K) & 12 & 0.007 & $\begin{array}{l}\text { Not Distributed } \\
\text { Normally }\end{array}$ \\
\hline Treatment $(P)$ & 12 & 0.581 & $\begin{array}{l}\text { Normally } \\
\text { Distributed }\end{array}$ \\
\hline
\end{tabular}

Source: research data, processed

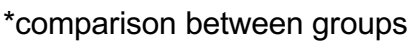

Based on the data in table 4 , the fetal birth weight of control group $(K)$ showed the spread of abnormal data $(p$ $<0.05)$, and the treatment group data $(P)$ showed the spread of normal data $(p>0.05)$.

Table 5. Results for Fetal Birth Weight Data of Homogeneity Test.

\begin{tabular}{ccc}
\hline Livene Statistic & Sig & Notes \\
\hline 1.473 & 0.238 & Homogeneous \\
\hline Source: research data, processed & \\
*comparison between groups &
\end{tabular}

Based on data in table 5, fetal birth weight data is homogeneous $(p>0.05)$.

Table 6. Results for Fetal Birth Weight Data of ManWhitney Test.

\begin{tabular}{cccc}
\hline \multicolumn{2}{c}{ Group Comparison } & $p$ & Notes \\
\hline Control $(\mathrm{K})$ & $\begin{array}{c}\text { Treatment } \\
(\mathrm{P})\end{array}$ & 0.043 & $\begin{array}{c}\text { Significantly } \\
\text { Different }\end{array}$ \\
\hline
\end{tabular}

Source: research data, processed

${ }^{*}$ comparison between groups

Based on the data in table 6 , it was shown that there was a significant difference between fetal birth weight of the control group $(K)$ and the treatment group $(P)(p<$ $0.05)$.

\section{Discussion}

\section{Danger of Cigarette Smoke Exposure}

Cigarettes introduced by Columbus are already known to almost all over the world. Not only those in large cities,cigarettes are also known in the countryside. Smoking is a habit which is well-known to adults and teenagers. In fact, children have smoked a lot of cigarettes so cigarettes are no longer a new thing in society. We cannot close our eyes to the people who smoke around us. They have the right to carry out these activities. Smoking habits start from trial and error and eventually become a smoking habit. In the article, Director of the Regional General Hospital Datusanggul Rantau said "In dealing with the development of smoking habits in Indonesia which is getting worse and worse, it seems that the hope of overcoming it becomes increasingly difficult". This is the reason why more adverse effects arise due to smoking habits.

The bad effect of cigarettes can be proven by the many diseases that arise due to smoking. The sense of calm given by cigarettes is basically pseudo, because when the calm effect of addictive substances on the cigarette runs out then all will return to normal, then smokers will smoke again to feel the sense of calm previously enjoyed. We will not feel the effects when smoking starts, slowly but surely the toxins foundin cigarettes begin to damage a healthy body. It can be said that cigarette is a time bomb that will suddenly explode. This illustrates that the negative effect of smoking is very large, not only felt by active smokers, but also by passive smoker. ${ }^{7}$ 
The effects of cigarettes in general are of two kinds, namely the effect on health and the effect on the environment. The effect of smoking on health already has a lot of evidence, some examples are disorders due to narrowing of blood vessels that can lead to coronary heart disease, pregnancy and fetal disorders, and strokes. According to WHO reports of 11 million deaths in advanced industries, 6 million were caused by blood circulation disorders, 2.5 million due to coronary heart disease, and 1.5 million due to stroke. The four main diseases that can cause and kill the most because of smoking are pulmonary disease, impotence, gastric disease, and stroke. ${ }^{9}$

\section{Normal Pregnancy}

Pregnancy begins with the meeting of ovum with sperm cells. This happens because sperm cells enter through the uterine tract to the fallopian tube during intercourse. When fertilization is successful, the fertilized ovum will continue to multiply and lead to the endometrium for implantation.

After implantation, the fertilized ovum will experience development which is divided into several phases. ${ }^{10}$ The first phase is the germinal phase, this phase occurs from fertilization until implantation occurs. The second phase is the embryonic phase, this is the phase of embryo growth. The third phase is the fetal phase, this phase is a continuation of the embryonic phase until birth.

The placenta has a large role in the process of pregnancy. While inside the womb, the foetus needs nutritional intake and oxygen circulation which are good in fulfilling its growth and development period. In addition, the foetus also needs a medium to remove the residual substances contained in its body. Nutrition will be obtained from what is consumed by the mother, then it will be distributed through the bloodstream to the foetus through the placenta. Similarly, oxygen inhaled by the mother will be distributed to the foetus through blood flow through the placenta. Besides, the placenta also has an important function in the distribution of waste disposal from the foetus to the mother. ${ }^{11}$ Thus, the research sample which is given exposure to cigarette smoke has the potential to distribute lots of dangerous chemicals through the bloodstream. This will adversely affect the quality of fetal growth and development in the womb, which was proven in this research by a significant value between the ratio of fetal birth weight to mice in the treatment group and the control group.

\section{The Effect of Cigarette Smoke on the Growth and Development of Foetuses}

The most sensitive growth and development of the foetus occur during fertilization until the end of the gastrulation period. ${ }^{12}$ The sensitive period will continue until the period of organ formation (organogenesis). ${ }^{13}$ When the foetus is exposed to toxic substances during that period, it will cause risk to the foetus to become disabled or dead. Based on the results in table 1 and 2, it described the results of observations of birth defects and stillbirth foetuses from the control and treatment groups. In both groups, no birth defects were found and the foetus was still born. It is because of the exposure to cigarette smoke which was not appropriate during fertilization and organogenesis of mice since there were several obstacles in determining the first day of mice pregnancy. In addition, this also indicates that fetal disability and death are things that can occur if influenced by many factors. ${ }^{14}$

Based on the results in table 6 , it showed the comparison of the results of fetal birth weight between the control and treatment groups with the $p$ value of $p<0.05$. This shows that there is a significant difference of the ratio of fetal birth weight between the two groups. The existence of this relationship indicates that cigarette smoke has a significant effect on fetal body weight in passively exposed mice. There is a significant relationship between passive smoking mothers and the incidence of Low Birth Weight (LBW). ${ }^{15}$ Exposure to cigarette smoke during pregnancy will increase 1.56 times the occurrence of low birth weight compared to mothers who are not exposed to cigarette smoke. ${ }^{16}$ This is due to the chemicals found in cigarettes. In a cigarette, there are approximately 200 out of 4000 chemicals that are harmful and carcinogenic to the body. ${ }^{17}$ There are 3 main chemicals that play a role in poisoning the body, namely nicotine, tar, and carbon monoxide (CO). ${ }^{18}$

Nicotine that enters the body will cause stimulation of the hormone catecholamine (adrenaline) which will stimulate the work of the heart and high blood pressure. ${ }^{19}$ This can change the heart rate and blood flow in the placenta blood vessels and induce hypoxia in the foetus in womb. Nicotine in cigarettes can also cause vasoconstriction of blood vessels in the placenta. ${ }^{20}$ The occurrence of vasoconstriction in the placenta blood vessels causes blood flow and supply of nutrients to the foetus to be disrupted.

Tar is a kind of dark brown or black thick liquid which is a hydrocarbon substance that is sticky and sticks to the lungs. Tar is also a polycyclic aromatic hydrocarbon which is contained in cigarette smoke, classified as a carcinogen, a substance that can cause health problems. Chronic exposure to aromatic hydrocarbons can produce very serious toxic effects. The most obvious effect is damages in the bone marrow resulting in aplastic anaemia. With the occurrence of anaemia, it will have a negative effect on the distribution of $\mathrm{O}_{2}$ to the foetus.

Carbon mono-oxide (CO) contained in inhaled cigarette smoke also has a negative effect on fetal growth and development. Carbon monoxide (CO) will compete with oxygen $\left(\mathrm{O}_{2}\right)$ to be bound to blood haemoglobin so that it can be distributed throughout the body. ${ }^{15}$ Carbon monoxide (CO) has the power 200 times stronger to bind to haemoglobin compared to oxygen $\left(\mathrm{O}_{2}\right) .{ }^{19}$ The competition between oxygen $\left(\mathrm{O}_{2}\right)$ and carbon monoxide (CO) results in reduced oxygen $\left(\mathrm{O}_{2}\right)$ in the mother's blood. Elements of carbon monoxide (CO) which binds to erythrocytes will form carboxyhemoglobin $(\mathrm{COHb})$. Carboxyhemoglobin cannot carry oxygen $\left(\mathrm{O}_{2}\right)$ so that the oxygen supply $\left(\mathrm{O}_{2}\right)$ from the mother to the foetus becomes reduced which makes the foetus become hypoxic.

In addition to the three main toxic substances above, cigarettes also contain lead $(\mathrm{Pb})$. Lead contained in cigarettes can be inhaled by active smokers and passive smokers. When lead enters the body, it is bound to erythrocytes and follows the bloodstream. Some of the absorbed lead will be deposited in several soft organs in the body (liver, kidneys, neurons) and mineral tissues (bones and teeth). Long bones are the biggest storage area for lead, this is due to the nature of $\mathrm{Pb}^{2+}$ ions which have similarities with $\mathrm{Ca}^{2+}$. Lead ions $\left(\mathrm{Pb}^{2+}\right)$ stored in bone can be redistributed through the bloodstream along with the formation of blood cells in the bone..$^{19}$ Lead absorbed in the body can inhibit the enzyme $\delta$-aminolevulinic acid dehydratase (ALAD) and ferrochelatase, both of which play an important role in erythrocyte synthesis. The inhibited enzyme $\delta$-aminolevulinic acid dehydratase (ALAD) will cause interference with porphobilinogen synthesis which results in iron in the formation of erythrocytes unable to enter the protoporphyrin cycle, 
whereas the inhibition of the ferrochelatase enzyme results in the accumulation of free erythrocyte protoporphyrin (FEP) or zinc protoporphyrin (ZPP) and coproporphyrin in urine. ${ }^{21}$ Erythrocyte protoporphyrin which is replaced by zinc protoporphyrin becomes increased and heme formation decreases, which can cause anaemia. ${ }^{19}$ Anaemia that occurs can adversely affect the growth and development of the foetus it contains.

Disruption of oxygen and nutrient supply from the mother to the foetus will cause disruption in the growth and development of the foetus which can cause low birth weight.

\section{Conclusion}

Based on the research, the following conclusions can be drawn: passive exposure to cigarette smoke does not have an effect on the fetal defect and fetal dead. Passive exposure to cigarette smoke can reduce fetal birth weight of the mice (Mus musculus).

\section{CONFLICT OF INTEREST}

The author stated there is no conflict of interest in this study.

\section{REFERENCES}

1.Organization WH. Leading Cause of Death, Illness and Impoverishment: (2017).

2.Indonesia KKR. Riset Kesehatan Dasar 2013. Jakarta: Badan Penelitian dan Pengembangan Kesehatan Kementerian Kesehatan Republik Indonesia, 2013.

3.Indonesia KKR. Jangan Biarkan Iklan, Promosi, dan Sponsor Rokok Mempengaruhi Generasi Muda: (2013).

4. Indonesia KKR. Pemerintah Terus Berupaya Kendalikan Dampak Merokok: (2012).

5.Indonesia KKR. Generasi Muda Sehat, Generasi tanpa Rokok: (2013).

6.Notoatmodjo S. Pendidikan dan Perilaku Kesehatan. Jakarta: PT Rineka Cipta, 2003.

7.Sukmana T. Mengenal Rokok dan Bahayanya. Jakarta: Be Champion, 2011.

8.Negoro RA. Perbandingan Efek Asap Rokok Konvensional dan Rokok Herbal terhadap Motilitas Spermatozoa Mencit (Mus musculus). Surakarta: Universitas Muhammadiyah Surakarta, 2016.
9.Indonesia KKR. Inilah 4 Bahaya Merokok Bagi Kesehatan Tubuh: (2015).

10. Hiryanto. Permulaan Kehidupan Manusia Yogyakarta: Universitas Negeri Yogyakarta, 2002.

11.Gude NM, Roberts CT, Kalionis B and King RG. Growth and Function of the Normal Human Placenta. Thrombosis Research. 2004; 114: 397-407.

12.Gilbert-Barness E. Teratogenic Causes of Malformations. Annals of Clinical and Laboratory Science. 2010; 40: 99-114.

13.Win Darmanto PWD, Prof. Win Darmanto, Drs. Msi. Med Sci. Ph.D. Pendekatan Teratologi Molekuler Sebagai Dasar Menurunkan Insiden Janin Cacat Serta Usaha Menciptakan Generasi Berkualitas. Airlangga University Press, 2011.

14.Ohana O, Holcberg G, Sergienko R and Sheiner E. Risk Factors For Intrauterine Fetal Death (1988-2009). The Journal of Maternal-Fetal \& Neonatal Medicine : The Official Journal of the European Association of Perinatal Medicine, The Federation of Asia and Oceania Perinatal Societies, The International Society of Perinatal Obstet. 2011; 24: 1079-83.

15.Ramadhan N. Hubungan Ibu Hamil Perokok Pasif dengan Kejadian Bayi Berat Lahir Rendah di Badan Layanan Umum Daerah RSU Meuraxa Banda Aceh. Jurnal IImiah STIKES U'budiyah. 2012; 1: 27-33.

16.Khader YS, Al-Akour N, Alzubi IM and Lataifeh I. The Association between Secondhand Smoke and Low Birth Weight and Preterm Delivery. Maternal and Child Health Journal. 2011; 15: 453-9.

17.Lee HJ, Choi NY, Park YS, Et Al. Multigenerational Effects of Maternal Cigarette Smoke Exposure during Pregnancy on Sperm Counts of F1 and F2 Male Offspring. Reproductive Toxicology (Elmsford, NY). 2018; 78: 169-77.

18.Mangoenprasodjo AS. Hidup Sehat Tanpa Rokok. Pradipta, 2005.

19.Chelchowska M, Ambroszkiewicz J, Jablonka-Salach $\mathrm{K}$, et al. Tobacco Smoke Exposure during Pregnancy Increases Maternal Blood Lead Levels Affecting Neonate Birth Weight. Biological Trace Element Research. 2013; 155: 169-75.

20.Endang $S$ and Sugian N. Pengaruh Rokok terhadap Berat Badan Bayi Baru Lahir. Jurnal Skala Kesehatan. 2014; 5

21.Ardyanto D. Deteksi Pencemaran Timah Hitam (Pb) Dalam Darah Masyarakat Yang Terpajan Timbal (Plumbum). 2005; 2. 